\title{
Label-Free Biosensor Detection of Endocrine Disrupting Compounds Using Engineered Estrogen Receptors
}

\author{
Rita La Spina ${ }^{1,+}{ }^{\dagger}$, Valentina E. V. Ferrero ${ }^{2,+}{ }^{,}$Venera Aiello ${ }^{1}$, Mattia Pedotti ${ }^{3}$, Luca Varani $^{3}$, \\ Teresa Lettieri ${ }^{2}$, Luigi Calzolai ${ }^{1}$, Willem Haasnoot ${ }^{4}$ and Pascal Colpo ${ }^{1, *}$ \\ 1 European Commission-DG Joint Research Centre, Directorate Health Consumer and Reference Materials, \\ 21027 Ispra, Italy; Rita.LA-SPINA@ec.europa.eu (R.L.S.); vaiello79@gmail.com (V.A.); \\ luigi.calzolai@ec.europa.eu (L.C.) \\ 2 European Commission-DG Joint Research Centre, Directorate Sustainable Resources, 21027 Ispra, Italy; \\ valentina.ferrero81@gmail.com (V.E.V.F.); teresa.lettieri@ec.europa.eu (T.L.) \\ 3 Institute for Research in Biomedicine, Università della Svizzera italiana (USI), 6500 Bellinzona, Switzerland; \\ mattia.pedotti@irb.usi.ch (M.P.); luca.varani@irb.usi.ch (L.V.) \\ 4 Authenticity \& Bioassays, RIKILT Wageningen University \& Research, Wageningen University, \\ 6708 WB Wageningen, The Netherlands; willem.haasnoot@wur.nl \\ * Correspondence: pascal.colpo@ec.europa.eu \\ + These authors contributed equally to this work.
}

Received: 1 December 2017; Accepted: 19 December 2017; Published: 22 December 2017

\begin{abstract}
Endocrine Disrupting Compounds (EDCs) are chemical substances shown to interfere with endogenous hormones affecting the endocrine, immune and nervous systems of mammals. EDCs are the causative agents of diseases including reproductive disorders and cancers. This highlights the urgency to develop fast and sensitive methods to detect EDCs, which are detrimental even at very low concentrations. In this work, we propose a label-free surface plasmon resonance (SPR) biosensor method to detect specific EDCs (17 $\beta$-estradiol (E2), ethinyl-estradiol, 4-nonylphenol, tamoxifen) through their binding to estrogen receptor alpha (ER $\alpha)$. We show that the use of rationally designed $\mathrm{ER} \alpha$ (as bio-recognition element) in combination with conformation-sensitive peptides (as amplification agent, resulting in increased responses) enables the detection of low parts per billion (ppb) levels of E2. As a proof of concept, this bioassay was used to detect E2 in (spiked) real water samples from fish farms, rivers and the sea at low ppb levels after concentration by solid phase extraction. In addition, the present SPR assay that combines a conformation-sensitive peptide with an array of ER $\alpha$ mutants is very promising for the assessment of the risk of potential estrogenic activity for chemical substances.
\end{abstract}

Keywords: estrogen receptor; $17 \beta$-estradiol; label-free assay; surface plasmon resonance; amplification; water

\section{Introduction}

Growing evidence in the last decades suggested that numerous chemicals, both natural and man-made, may interfere with the endocrine system and produce adverse effects in animals and humans. Scientists often refer to these chemicals as Endocrine Disrupting Compounds (EDCs).

These chemicals are found in many commercial products, such as plastic bottles, containers, metal food cans, detergents, flame-retardants, food, toys, cosmetics, drugs and pesticides.

$17 \beta$-Estradiol (E2) and other natural hormones, natural chemicals, man-made chemicals and pharmaceutical products [1], are considered as EDCs because of their ability to mimic the effect of endogenous hormones [2]. They can interfere with the endocrine, immune and nervous systems of 
mammals [3]. Many of these EDCs have been found in the environments at very low concentration [4], but chronic low-level exposure might cause adverse biological effects in animals and humans [5]. For this reason, the REACH regulation (Registration, Evaluation, Authorisation and Restriction of Chemicals) imposes high level of protection for human health and the environment to the manufacturers of chemicals in the EU. To address these issues, simple, fast, accurate and sensitive methods for screening these compounds are required [6]. The most sensitive methods currently available for the detection of (anti)estrogenic activity are cell-based assays such as ER-CALUX, MELN, T47D-KBLuc and the Yeast Estrogen Screen (YES) assays [7]. Although these methods have been successfully developed to overcome animal testing and reach limit of detection of pg-ng/L, they have the disadvantages to require $24 \mathrm{~h}$ for test completion and specific laboratories equipment and personnel. In contrast, several bioanalytical techniques have been developed based on optical and electrochemical detection, in which the bio-recognition elements are usually antibodies, enzymes, receptors, nucleic acid, or whole cells [8]. Label free, antibody-based immuno-sensors have been used for environmental detection of EDCs [9-13], but the cost and difficulties to produce specific antibodies to different EDCs remains a limitation.

Interesting approaches using estrogen receptor proteins (ER) as a biorecognition element have been proposed as alternative methods to the use of antibodies [10]. ER $\alpha$ is a member of the superfamily of nuclear receptors [14-16] activating signaling pathways that regulate biological processes such as reproduction, embryonic development and homeostasis [17-20]. ER $\alpha$ is composed by five domains, three of which are well-structured functional domains: a modulating domain, a DNA-binding domain (DBD) and a ligand binding domain (LBD) [21-23]. Binding of ligands to the LBD of the wild type estrogen receptor (wt-ER $\alpha^{\mathrm{LBD}}$ ) induces conformational changes, which in turn affect and regulate the hormonal pathways. In the presence of agonist ligands the so-called helix 12, which lies over the ligand-binding cavity, changes position in the presence of agonist or antagonist ligands. Different positioning of helix 12 and associated changes in other helices of wt-ER $\alpha$ result in different co-regulator binding surfaces and hence underlie the different physiological effects of agonists and antagonists compounds [24-27]. Rationally designed mutants in the ER $\alpha^{\mathrm{LBD}}$ were produced to increase the affinity towards specific agonist/antagonist compounds [28] by replacing residue methionine (M) 421 with isoleucine (I) or phenylalanine (F). In comparison to wt-ER $\alpha^{\mathrm{LBD}}$, M421F-ER $\alpha^{\mathrm{LBD}}$ exhibits stronger binding affinity for E2, ethinyl-estradiol (EE2), and 4-nonylphenol (4-NP) whereas M421I-ER $\alpha^{\text {LBD }}$ has lower binding affinity for all investigated compounds compared to wt-ER $\alpha^{\mathrm{LBD}}[28]$.

wt-ER $\alpha$ has been used to detect agonist/antagonist compounds in in vitro tests based on bioaffinity mass spectroscopy [29] and surface plasmon resonance (SPR) approaches [30,31]. However, the limits of detection are still orders of magnitude higher than those of cell culture bioassays. The advantage of using bioanalytical tools is their direct applicability for continuous assessment of EDCs [32]. SPR has been shown to be a versatile technique for biosensor applications [33] and novel and portable SPR devices are under development [34]. In addition, direct detection of agonist/antagonist compounds using label-free biosensors is challenging because their low molecular weights (typically <500 Da) are close to the inherent limit of detection of most label-free techniques [31].

An interesting method to bypass this problem is to exploit the ability of ER to change conformation upon ligand binding. Indeed, $\alpha \beta / \mathrm{I}$ peptide, a specific peptide motif belonging to ER interacting proteins, was demonstrated to recognize the active conformation of wt-ER $\alpha^{\mathrm{LBD}}$ [35-37].

Here we propose an SPR based label free method that exploits both the ER $\alpha^{\mathrm{LBD}}$ and a peptide $(\alpha \beta / \mathrm{I})$ able to recognize the active conformation of agonist ligand bound $\operatorname{ER} \alpha^{\mathrm{LBD}}$. Different compounds, such as E2, can act as ER agonist molecules, promoting an ER active conformation that is specifically recognized by the $\alpha \beta$ /I peptide. By contrast, binding of antagonist compounds such as tamoxifen causes conformational changes that prevent ER from binding the $\alpha \beta / \mathrm{I}$ peptide. In our proposed method, the specific binding of ligands is monitored through the ER interaction with the $\alpha \beta$ /I peptide immobilized on an SPR sensor surface and used as recognition and amplification element. 
The assay is performed by incubating ER $\alpha^{\mathrm{LBD}}$ with $\mathrm{E} 2$ and we show that the SPR binding response is directly related to the concentration of ligand bound to $E R \alpha^{\mathrm{LBD}}$. Moreover, screening of an array of engineered estrogen receptors (wt-ER $\alpha^{\mathrm{LBD}}, \mathrm{M} 421 \mathrm{~F}-\mathrm{ER} \alpha^{\mathrm{LBD}}, \mathrm{M} 421 \mathrm{I}-\mathrm{ER} \alpha^{\mathrm{LBD}}$ and Y537S-ER $\alpha^{\mathrm{LBD}}$ ) with a set of agonist and antagonist ligands shows that the assay is a fast method to detect the estrogenic activities of E2, EE2, 4-NP and tamoxifen. As a proof of concept, the wt-ER $\alpha^{\mathrm{LBD}}$-based assay was applied to the detection of estrogen activity in water samples; the procedure and experimental conditions were adapted to create a robust and reproducible assay with great promise for future applications.

\section{Materials and Methods}

\subsection{Materials and Reagents}

Endocrine disrupting compounds (EDCs) such as $17 \beta$-estradiol (E2), ethinyl-estradiol(EE2), 4-nonylphenol (4-NP) and 4-OH tamoxifen (TAM) were purchased from Sigma-Aldrich (St. Louis, MO, USA). Stock solutions of all ligands were prepared in methanol; for SPR measurements, the stock solutions were further diluted with methanol into a series of concentrations, and then added to the final working samples in order to obtain the right ligand concentration and a final methanol percentage of $2 \%$. Biotinylated-Dioxa (AEEA) and amine terminated peptides $\alpha \beta / \mathrm{I}$ (SSNHQSSRLIELLSR) are synthesized by Primm Srl (Milan, Italy). All the other reagents were acquired from general laboratory suppliers with analytical purity. Solutions were prepared in deionized water from water purification system MMilli-Q ${ }^{\circledR}$ Integral (Millipore-Merck, Burlington, MA, USA).

\section{2. $E R \alpha^{L B D}$ Production and Purification}

Wild-type ER $\alpha^{\mathrm{LBD}}$ and its mutants were expressed in high yield in E. coli Rosetta 2(DE3)pLysS cells with a pET21 vector (Novagen) and then purified as previously described [28].

Single point mutants were generated by site-directed mutagenesis of the vector encoding the wild-type sequence using the QuickChange site-directed mutagenesis kit (Stratagene). The introduction of the desired mutations was confirmed by DNA sequencing. The PCR products are transformed into XL10-Blue supercompetent E. coli cells (Stratagene) and the plasmids purified according to standard techniques and transferred in E. coli Rosetta 2(DE3)pLysS cells for protein production.

\subsection{Design of the Binding Assay}

The SPR label-free binding assay is based on the ability of $\alpha \beta /$ I peptide to recognize a ligand bound conformation of ER (also called active conformation upon agonist binding). Figure 1 is a schematic representation of the assay: $\alpha \beta$ /I biotinylated peptide (peptide in yellow) able to recognize the active conformation of the ER $\alpha^{\mathrm{LBD}}$ (violet) was directly immobilized on a neutravidin coated surface. After immobilization of the $\alpha \beta / \mathrm{I}$, pre-incubated $\mathrm{ER} \alpha{ }^{\mathrm{LBD}}$-ligand complex solutions were flowed over the peptide functionalized surface and the binding event of $\mathrm{ER} \alpha^{\mathrm{LBD}}$-ligand onto $\alpha \beta / \mathrm{I}$ peptide was monitored. In case an agonist molecule (magenta) is bound to ER $\alpha^{\mathrm{LBD}}$, helix 12 (green) moves creating a conformation that is recognized by the $\alpha \beta / \mathrm{I}$ peptide. When ER $\alpha^{\mathrm{LBD}}$ is free (un-liganded) or antagonist bound (orange), helix 12 might create a conformation that is not recognized by the $\alpha \beta /$ I peptide.

Monitoring the amount of $\mathrm{ER} \alpha^{\mathrm{LBD}}$-E2 complex bound onto $\alpha \beta / \mathrm{I}$ peptide is a direct detection of $\mathrm{E} 2$, because the amount of detected $\mathrm{ER} \alpha^{\mathrm{LBD}}$-E2 is proportional to the $\mathrm{E} 2$ concentration. The advantage of this assay format is that it is based on the recognition of a large molecule (the $\mathrm{ER} \alpha^{\mathrm{LBD}}-\mathrm{E} 2$ complex is around $29 \mathrm{kDa}$ ), which circumvents the issue related to the detection of small molecules (for instance E2 is $273.82 \mathrm{Da}$ ) with low responses in SPR-based detection methods. 


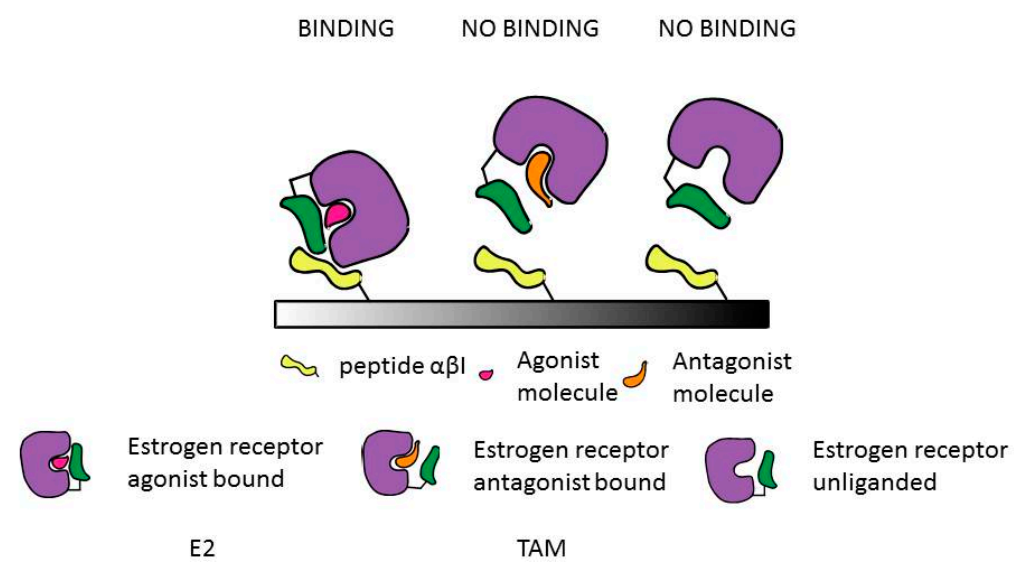

Figure 1. Schematic representation of the approach used for the detection of ER $\alpha^{\mathrm{LBD}}$ agonist and antagonist compounds.

\subsection{SPR Measurements}

\subsubsection{ProteOn XPR36 ${ }^{\mathrm{TM}}$}

All the binding experiments were performed with a ProteOn XPR36 ${ }^{\text {TM }}$ SPR instrument (BioRad), at $25{ }^{\circ} \mathrm{C}$ using a neutravidin modified chip (NLC sensor chip, BioRad, Hercules, CA, USA). With this instrument a $6 \times 6$ interaction array for the simultaneous analysis of thirty-six different experimental conditions was generated. NLC is a sensor chip with a neutravidin protein immobilized into a matrix of alginate polymer. The further coupling on the chip exploits the specific binding between neutravidin and biotinylated molecules. The chip was activated according to the manufacturer's instructions by sequentially injecting $1 \mathrm{M} \mathrm{NaCl}$ and $50 \mathrm{mM} \mathrm{NaOH}$ for $60 \mathrm{~s}$ at $30 \mu \mathrm{L} / \mathrm{min}$. The immobilization of biotinylated peptide $(\alpha \beta / \mathrm{I})$ on the NLC chip surface was done in $20 \mathrm{mM}$ Tris- $\mathrm{HCl}, \mathrm{pH} 8,20 \mathrm{mM}$ $\mathrm{NaCl}$ (buffer A) for $300 \mathrm{~s}$ at $30 \mu \mathrm{L} / \mathrm{min}$. The subsequent injection of ER $\alpha^{\mathrm{LBD}}$-ligand complex was done in $100 \mathrm{mM}$ potassium phosphate buffer, $\mathrm{pH} 7.2,20 \mathrm{mM} \mathrm{NaCl}, 2 \%$ methanol (buffer B) for $240 \mathrm{~s}$ at $100 \mu \mathrm{L} / \mathrm{min}$. The biotinylated $\alpha \beta /$ I peptide was immobilized in vertical way (left panel, Figure S1) and the peptide surface was, then, washed with buffer B for one hour. ER $\alpha^{\mathrm{LBD}}$-ligand complexes were then flowed over the $\alpha \beta$ /I peptide in horizontal way (right panel, Figure S1), and its binding was monitored.

For each binding measurement, triplicate independent solutions were prepared for receptor-ligand mixture under investigation. Error was calculated using triplicates.

To assess the amount of immobilized peptide leading to an optimal SPR response, five different concentrations of peptides $(0.1,0.6,1.4,2.2$ and $17 \mu \mathrm{g} / \mathrm{mL}$ ) were injected in 5 channels (Figure S1, vertical way), and one channel was used as reference with buffer $A$.

To determine the best peptide concentration for $\mathrm{ER} \alpha^{\mathrm{LBD}}$-ligand binding, a mixture of ER $\alpha^{\mathrm{LBD}}$ $(4 \mu \mathrm{g} / \mathrm{mL}, 134 \mathrm{nM})$ and E2 $(405 \mathrm{ng} / \mathrm{mL}, 1.5 \mu \mathrm{M})$ was prepared and flowed over the different peptide concentrations. Buffer $\mathrm{B}$ and free $\mathrm{ER} \alpha^{\mathrm{LBD}}$ were injected at the same time as controls.

To determine the limit of quantification of our assay, mixtures of wt-ER $\alpha^{\mathrm{LBD}}(134 \mathrm{nM})$ were prepared and incubated with different E2 concentrations $(0.03,0.3,0.8,2.7,4,8,12,27 \mathrm{ng} / \mathrm{mL}$ and $405 \mathrm{ng} / \mathrm{mL}$ ). Buffer solution and $\mathrm{wt}-\mathrm{ER} \alpha^{\mathrm{LBD}}$ without ligand were prepared and injected at the same time as controls. After each measurement, the peptide functionalized surface was regenerated by injecting $10 \mathrm{mM} \mathrm{H}_{3} \mathrm{PO}_{4}$ for $20 \mathrm{~s}$ at $100 \mu \mathrm{L} / \mathrm{min}$ in both flow directions to remove the ER $\alpha^{\mathrm{LBD}}$-ligand complex from the modified functionalized peptide surface. Triplicate measurements were performed for each receptor-ligand concentration under investigation.

To test the specific interaction of the estrogen receptors towards the $\alpha \beta / \mathrm{I}$ peptide, the same experiments of binding were performed with transthyretin protein (TTR), which is not supposed to bind the peptide. TTR at $134 \mathrm{nM}$, without and with E2 at $1.5 \mu \mathrm{M}$ was injected onto the peptide coated surface and the SPR signal monitored. 
Furthermore, experiments were performed to determine the affinity of the $\alpha \beta$ /I peptide to the $w t-E R \alpha^{\text {LBD }}-E 2$ complex. Serial dilutions of $w t-E R \alpha^{\text {LBD }}-E 2$ were prepared starting from $w t-E R \alpha^{\mathrm{LBD}}$ $134 \mathrm{nM}$ and E2 $200 \mathrm{nM}$, then diluting 1:2 for five times. The wt-ER $\alpha^{\mathrm{LBD}}$-E2 complex solutions were then flushed over the peptide coated surface and each binding curve is fitted to Langmuir isotherm.

To screen the binding abilities of $\mathrm{ER} \alpha^{\mathrm{LBD}}$ mutants bound to selected ligands, receptors were pre-incubated and then flowed over the peptide surface. Respectively $134 \mathrm{nM} w \mathrm{t}-\mathrm{ER} \alpha^{\mathrm{LBD}}$, M421F-ER $\alpha^{\mathrm{LBD}}$, M421I-ER $\alpha^{\mathrm{LBD}}$ and Y537S-ER $\alpha^{\mathrm{LBD}}$ were injected as free receptor, or incubated with $1.5 \mu \mathrm{M}$ E2, EE2, 4-NP and TAM. The reference solutions were prepared by adding $2 \%$ methanol to buffer $\mathrm{B}$ alone and to $\mathrm{ER} \alpha^{\mathrm{LBD}}$ solutions without ligand. ER $\alpha^{\mathrm{LBD}}$-ligand, $\mathrm{ER} \alpha^{\mathrm{LBD}}$-methanol and the buffer-methanol mixtures were incubated for $1 \mathrm{~h}$ at $4{ }^{\circ} \mathrm{C}$. Triplicate solutions were prepared for each receptor-ligand mixture under investigation.

\subsubsection{Biacore 3000}

The binding experiments and water sample analyses were performed with a Biacore 3000 and carried out by immobilization of the amine-peptide directly to a CM5 chip. The amine terminated $\alpha \beta / \mathrm{I}$ peptide was dissolved in acetate-buffer $(\mathrm{pH} 4.5)$ in a concentration of $100 \mu \mathrm{g} / \mathrm{mL}$ and injected over an EDC/NHS activated CM5 chip surface and a response of 800 RU was recorded.

The final optimized assay conditions were as follows: $100 \mu \mathrm{L}$ of the wt-ER $\alpha^{\mathrm{LBD}}(60 \mathrm{nM})$ in HBS-EP (10 mM Hepes, $150 \mathrm{mM} \mathrm{NaCl}, 3 \mathrm{mM}$ EDTA, 0.005\% Tween-20) buffer was mixed in the Biacore with $100 \mu \mathrm{L}$ of E2 standard/sample in $20 \%$ methanol and of this mixture $90 \mu \mathrm{L}$ was injected at $30 \mu \mathrm{L} / \mathrm{min}$ with HBS-EP as running buffer which was followed by the injection of $10 \mathrm{mM} \mathrm{NaOH}$ for $0.5 \mathrm{~min}$ for the regeneration. For calibration, E2 concentrations of $0.63,1.25,2.5,5,10$ and $20 \mathrm{ng} / \mathrm{mL}$ were used. This bioassay was then used to test (spiked) Milli Q (MQ) water, tap drinking water, tap process water, real field water samples from fish tanks coming from the UK and river and sea water samples coming from Slovenia. The water samples were spiked with different concentrations of E2 (10, 20 or $50 \mathrm{ng} / \mathrm{L}$ (ppt)) and concentrated with by Solid Phase Extraction (SPE) for 200 times prior to SPR assay. The final sample extract contained $20 \%$ of methanol.

Furthermore, the real field water samples were analysed with the bioassay and the results compared with GC-MS (Gas chromatography-mass spectrometry) data.

\subsection{Water Sample Preparation by SPE}

Field water samples were kept frozen until the day before being analysed. The thawed water sample was filtered through a folder paper filter (S\&S 595 1/2) with a pore size of $4-7 \mu \mathrm{m}$ ) followed by an Acrodisc syringe filter of $0.45 \mu \mathrm{m}$ (Pall) to avoid clogging of the SPE column (as was experienced before). Sample volumes of 200 or $500 \mathrm{~mL}$ of the filtered water were brought to $\mathrm{pH} 5.2$ by the addition of $5 \mathrm{~mL}$ of acetate buffer ( $\mathrm{pH}$ 5.2). Hereafter, $50 \mu \mathrm{L}$ of Helix Pomatia was added and the whole left overnight at $37^{\circ} \mathrm{C}$ (mild shaking in a water bath). The column (Bond Elut C18 $3 \mathrm{cc} / 500 \mathrm{mg}$ of Varian (1210-2028) was activated by passing through $2.5 \mathrm{~mL}$ of methanol followed by $2.5 \mathrm{~mL}$ sodium acetate buffer ( $\mathrm{pH} 4.8$ ). The water sample was passed through the column, and thereafter the column was washed with $1.5 \mathrm{~mL}$ of sodium acetate buffer, $3 \mathrm{~mL}$ of water, $1.5 \mathrm{~mL}$ sodium carbonate buffer, $3 \mathrm{~mL}$ water and $2 \mathrm{~mL}$ methanol/water $(50 / 50 ; v / v)$. The column was dried and eluted with $4 \mathrm{~mL}$ of acetonitrile. After overnight storage, the eluates contained solids and they were removed by filtration (Whatman no. 1), the filter was washed with acetonitrile and it was evaporated and dissolved in $200 \mu \mathrm{L}$ of methanol. This was divided in 4 portions of $50 \mu \mathrm{L}$, representing $50 \mathrm{~mL}$ of water sample each, and stored in closed vials at $4-6{ }^{\circ} \mathrm{C}$ until analysed by the Biacore 3000 .

\subsection{GC-MS Analysis}

The multi residue method (RIKILT SOP 1160) was developed for the detection of 27 anabolic compounds (including E2 and EE2) from 0-1 $\mathrm{g} / \mathrm{L}$. Of the methanol extracts of the water samples, $25 \mu \mathrm{L}$ portions (equivalent to $25 \mathrm{~mL}$ of water) were evaporated and $25 \mu \mathrm{L}$ of the derivatization reagent 
$N$-methyl- $N$-trimethyl silyltrifluoroacetamide (MSTFA) was added. The vials were vortexed and the reaction mixture was incubated during $1 \mathrm{~h}$ at $60^{\circ} \mathrm{C}$. After incubation, the reaction mixture was evaporated to dryness under a stream of nitrogen at $55^{\circ} \mathrm{C}$. The residue was dissolved in $50 \mu \mathrm{L}$ of isooctane and transferred into a glass injection insert and transferred into the automatic injector (Varian, type CP-8400, Varian, Inc, Walnut Creek, CA, USA) of the GC-MS-MS (Varian type CP-3800 and type $1200 \mathrm{~L}$, (Varian, Inc, Walnut Creek, CA, USA) and $2 \mu \mathrm{L}$ were injected into the GC-column (VF-17MS, $30 \mathrm{~m} \times 0.25 \mathrm{~mm}$ ID, film thickness $0.15 \mu \mathrm{m}$ (Varian CP8981, Varian, Inc, Walnut Creek, CA, USA).

\section{Results and Discussion}

\subsection{Optimisation of the Assay Parameters}

Optimization of the procedure for peptide coating of the SPR surface and ER $\alpha^{\mathrm{LBD}}$ concentration was performed on the ProteOn XPR36 ${ }^{\mathrm{TM}}$ (BioRad, Hercules, CA, USA). Biotinylated $\alpha \beta /$ I peptides were immobilized on a neutravidin modified sensor chip to form a monolayer through the biotin-neutravidin specific interaction. To determine the amount of immobilized peptide leading to an optimal SPR response, five different $\alpha \beta /$ I peptide concentrations $(0.06,0.25,0.6,1.0$ and $7.5 \mu \mathrm{M})$ were flowed over the sensor surface (Figure S2. SI, Panel A). Buffer A without peptide was used in the reference channel (Figure S2. SI, Panel A, black continuous line). The amount of $\alpha \beta /$ I peptide bound to neutravidin on the surface was determined and the corresponding SPR response plotted versus the peptide concentration in Figure S2. (SI, Panel B). A maximum of 650 SPR response units (RU) was determined for the peptide immobilization, with a signal variation of $8 \%$. In addition, the binding response reached a plateau for peptide concentrations higher than $1 \mu \mathrm{m}$.

For the optimization of the assay, E2 was chosen as model-ligand due to its high affinity towards the $\mathrm{ER} \alpha^{\mathrm{LBD}}$ binding pocket. Indeed, $\mathrm{E} 2$ generates the active conformation of $\mathrm{ER} \alpha^{\mathrm{LBD}}$ (agonist bound) specifically recognized by the $\alpha \beta /$ I peptide. Preliminary tests with a range of $E R \alpha^{\mathrm{LBD}}$ concentrations from 10 to $200 \mathrm{nM}$ were performed to determine the optimal amount of receptor to be used for the following experiments (data not shown).

$w \mathrm{t}-\mathrm{ER} \alpha^{\mathrm{LBD}}$ concentration of $134 \mathrm{nM}$ was found to provide a high response signal and used for the subsequent experiments. ER $\alpha^{\mathrm{LBD}}$ and $\mathrm{E} 2$ at the saturating concentration of $1.5 \mu \mathrm{M}$ were pre-incubated for $45 \mathrm{~min}$ at $4{ }^{\circ} \mathrm{C}$ and then injected on SPR channels functionalized with different amounts of $\alpha \beta / \mathrm{I}$ peptide (Figure S3. SI).

The signal resulting from the binding of the wt-ER $\alpha^{\mathrm{LBD}}-\mathrm{E} 2$ complex on the peptide-coated chip increases with the amount of immobilized peptide (Figure S3. SI, Panel A). A signal plateau around $1100 \mathrm{RU}$, corresponding to the saturation of wt-ER $\alpha^{\mathrm{LBD}}-\mathrm{E} 2$ complex on the surface, was found at peptide concentration above $0.6 \mu \mathrm{M}$ (Figure S3. SI, Panel B), which was selected for subsequent experiments since it provides satisfactory signal to noise ratio and a good coverage of the surface. Furthermore, the affinity of the $\alpha \beta / \mathrm{I}$ peptide to the wt-ER $\alpha^{\mathrm{LBD}}$-E2 complex was measured as described in materials and methods. An apparent average $K_{D}$ value of $2.5 \times 10^{-9} \pm 0.7 \times 10^{-9} \mathrm{M}$ was determined.

The specificity of the interaction of the estrogen receptors with the $\alpha \beta /$ I peptide in our assay was verified by replacing ER with an unrelated protein with similar surface charge, TTR.

No SPR response was detected when $134 \mathrm{nM}$ TTR, without and with E2 at $1.5 \mu \mathrm{M}$, was injected over the $\alpha \beta$ /I peptide coated surface (Figure S4. SI).

Reproducibility of the SPR measurements and regeneration of the chip surface were also tested. After binding of $\mathrm{wt}-\mathrm{ER} \alpha^{\mathrm{LBD}}$-E2 complex to the immobilized $\alpha \beta / \mathrm{I}$ peptide (Figure S5. SI, Step 1), the ER was removed by washing the SPR chip with $10 \mathrm{mM} \mathrm{H}_{3} \mathrm{PO}_{4}$ at $30 \mu \mathrm{L} / \mathrm{min}$ for $18 \mathrm{~s}$ (contact time with the chip) [38], regenerating the peptide surface for further testing (Figure S5. SI, Regeneration 1). After regeneration, the wt-ER $\alpha^{\mathrm{LBD}}$-E2 complex was flowed over the peptide surface as before. The procedure was repeated twice (Figure S5. SI, Step 2, Regeneration 2, Step 3). Repeated injections of the same wt-ER $\alpha^{\mathrm{LBD}}-\mathrm{E} 2$ complex solution before and after regeneration gave similar SPR responses 
(Figure S5. SI) with reproducibility within 6\% of variation. These experiments demonstrate that the peptide coated surface can be successfully regenerated. The ease and effectiveness of the regeneration steps and the reproducibility of the SPR response are a key asset for the assay. Furthermore, the test can be completed in significantly shorter time than that required by cell-based assays. Surface activation and peptide immobilization are performed in $20 \mathrm{~min}$; injection of the wt-ER $\alpha^{\mathrm{LBD}}-\mathrm{E} 2$ and determination of its binding response are achieved in only $4 \mathrm{~min}$. After that, the SPR chip can be regenerated, washed and be ready for further ER injections and testing.

\subsection{Limit of Detection, Sensitivity and Specificity of the Assay for $w t E R \alpha^{L B D}$ and $E 2$}

After optimization of the assay, the limit of detection (LoD) for the $w \mathrm{tER} \alpha^{\mathrm{LBD}}-\mathrm{E} 2$ system was determined by preparing mixtures of $134 \mathrm{nM} w \mathrm{t}-\mathrm{ER} \alpha^{\mathrm{LBD}}$ with increasing amounts of E2, ranging from 0.1 to $1.5 \mu \mathrm{M}$. The wt-ER $\alpha^{\mathrm{LBD}}$-E2 mixtures and the wt-ER $\alpha^{\mathrm{LBD}}$ ligand free solutions were prepared in triplicate, incubated at $4{ }^{\circ} \mathrm{C}$ for one hour and injected over the sensor surface. E2 binding to wt-ER $\alpha^{\mathrm{LBD}}$ generates an ER active conformation (agonist bound) specifically recognized by the $\alpha \beta /$ I peptide. Binding of ER $\alpha^{\mathrm{LBD}}$ to the immobilized peptide is expected to produce an SPR signal proportional to the amount of E2, since the ER concentration is kept constant in our assay. The SPR responses for different E2 concentrations are shown in Figure 2, Panel A. The SPR response recorded $60 \mathrm{~s}$ after the end of injection was used for quantification purposes. Increasing concentrations of E2 generate a proportional increase of signal response. Injection of ligand free $w t-E R \alpha^{L B D}$ results in a SPR response of $300 \mathrm{RU}$ within $10 \%$ error, whereas wt-ER $\alpha^{\mathrm{LBD}}-\mathrm{E} 2$ complex at $1.5 \mu \mathrm{M}$ E2 shows a SPR response of $1200 \mathrm{RU}$ within an error of $6 \%$. The signal response can be fitted with a linear regression up to $30 \mathrm{nM}$ with $\mathrm{R}^{2}$ of 0.9 . A plot of the SPR response of wt-ER $\alpha^{\mathrm{LBD}}$-E2 binding to the $\alpha \beta / \mathrm{I}$ peptide versus the E2 concentration is shown in Figure 2, Panel B.

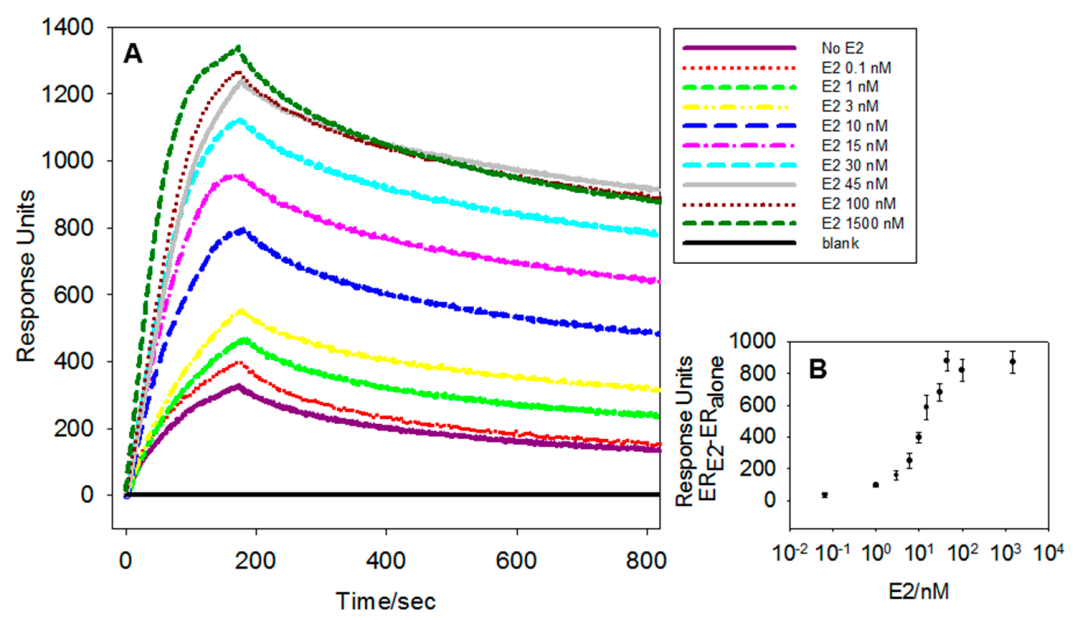

Figure 2. (A) Surface plasmon resonance (SPR) sensorgrams of the interaction between $134 \mathrm{nM}$ wt-ER $\alpha^{\text {LBD }}$ with different E2 concentrations $(0.1,1,3,10,15,30,45,100,1500 \mathrm{nM})$; (B) The SPR signal recorded $60 \mathrm{~s}$ after the injection and is plotted as a function of E2 concentration.

The limit of detection (LoD) was defined as the E2 concentration producing an SPR response above the response of the ligand free wt-ER $\alpha^{\mathrm{LBD}}$ (300 RU) plus 3 times the standard deviation $(3 \times 30 \mathrm{RU})$,corresponding to $1 \mathrm{nM}$ or $0.20 \mathrm{ng} / \mathrm{mL}$ of E2. This LoD, although higher than that of LC-MS or radioimmunoassay based methods $[39,40]$, this is equal or higher to the typical concentration of E2 found in contaminated real water samples. For instance, the concentration of E2 in the river Ahr at Blankenheim is in the order of 4-12 ng/L [41] and 122-631 ng/L in Rio de la Plata, Argentina [42]. However, the LoD could be further improved by pre-concentrating the sample through, for instance, the use of SPE columns or miniaturized pre-concentration column tools as the one developed by Heub S. et al. [43]. 


\subsection{Testing Water Samples}

For testing water samples, the bioassay was optimized with just one wt-ER $\alpha^{\mathrm{LBD}}$ concentration $(1 \mu \mathrm{g} / \mathrm{mL})$ and one $\alpha \beta /$ I peptide amount (800 RU) coated on the chip surface, to create the fastest, most robust and easiest to apply assay format suitable for routine testing. In this case, the amine terminated $\alpha \beta /$ I peptide was immobilized over an EDC/NHS activated CM5 chip. For calibration, several solutions of wt-ER $\alpha^{\mathrm{LBD}}$-E2 complex with different concentrations of E2 were prepared and injected over the $\alpha \beta$ /I peptide. This coated biosensor chip could be used for more than 150 injections of samples/standards, and for weeks. The mixing $(1: 1 ; v / v)$ of the wt-ER $\alpha^{\mathrm{LBD}}$ solution $(60 \mathrm{nM}$ ( $1 \mu \mathrm{g} / \mathrm{mL}$ in HBS-EP buffer) ) with the standards and samples (in 20\% methanol) was performed automatically in the Biacore 3000 and at room temperature creating similar incubation times between injections. No pre-incubation of the complex between wt-ER $\alpha^{\mathrm{LBD}}$-E2 was applied because of the limited effect on the SPR responses. Therefore, the assay was carried out faster. In addition, the amount of methanol in the sample was varied between 0 and $20 \%$ and only a little signal reduction was observed with methanol $>2 \%$ but a clear difference between the blank and positive samples was recorded. This result is very convenient because it allowed testing of the SPE eluate in methanol after less dilution (5 times only). Moreover, the use of HBS-EP buffer, as ER $\alpha$ dilution and running buffer showed larger differences between the blank and positive samples/standards in comparison to the phosphate buffer. Regarding the stability of ER $\alpha$, it was found that diluted ER $\alpha$ could be stored during 1 week at $4-6{ }^{\circ} \mathrm{C}$ which is convenient for routine testing, whereas better regeneration was recorded by the10 $\mathrm{mM} \mathrm{NaOH}$ for $0.5 \mathrm{~min}$ compared to $10 \mathrm{mM} \mathrm{H}_{3} \mathrm{PO}_{4}$ as applied in the ProteOn XPR36 ${ }^{\mathrm{TM}}$. Overall, the assay time, including transferring and mixing of the ER $\alpha$ and the standards/samples and applying a $3 \mathrm{~min}$ injection at $30 \mu \mathrm{L} / \mathrm{min}$ and $1 \mathrm{~min}$ regeneration, was $11 \mathrm{~min}$. These easy, fast and stable conditions made the test more suitable for routine testing. An example of an unreferenced (without the subtraction of the reference channel response) sensorgram is shown in Figure S6 and referenced sensorgrams and the calibration curve are shown in Figure 3 and the LoD was determined as $0.6 \mathrm{ng} / \mathrm{mL}$.

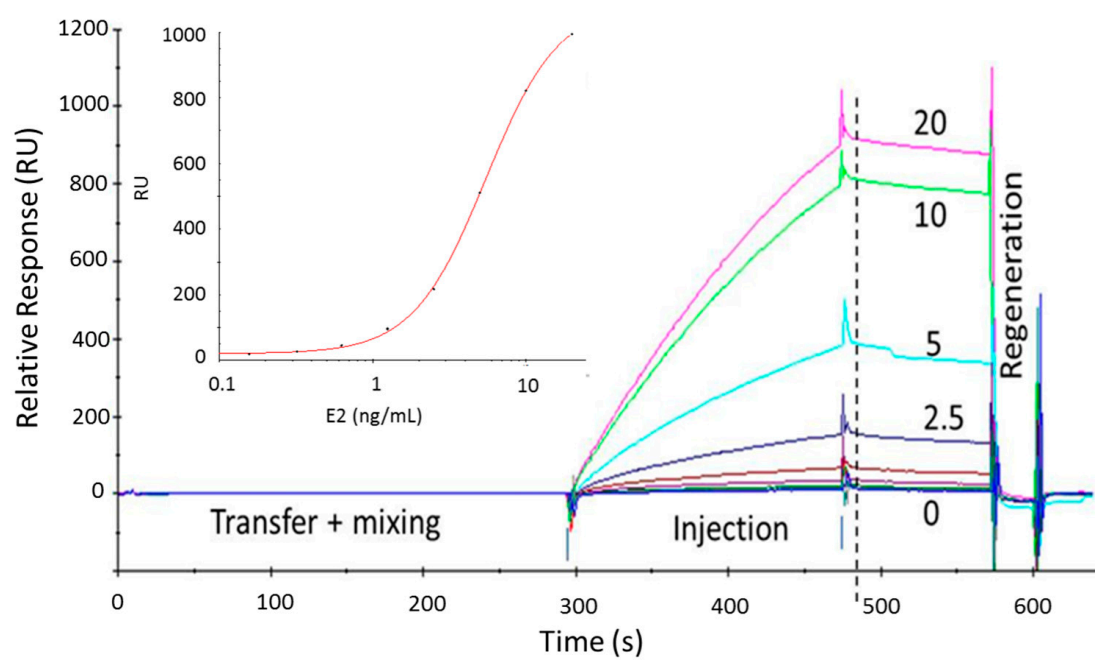

Figure 3. Referenced SPR sensorgrams obtained in the Biacore 3000 with E2 concentrations ranging from 0 to $20 \mathrm{ng} / \mathrm{mL}$. The standard solutions in $20 \%$ methanol and the $w \mathrm{t}-\mathrm{ER} \alpha^{\mathrm{LBD}}$ in HBS-EP $(10 \mathrm{mM}$ Hepes, $150 \mathrm{mM} \mathrm{NaCl}, 3 \mathrm{mM}$ EDTA, 0.005\% Tween-20) buffer were transferred and mixed in the Biacore $(1: 1 ; v / v)$. Of this mixture, $90 \mu \mathrm{L}$ was injected over the peptide-coated sensor surface at a flow rate of $30 \mu \mathrm{L} / \mathrm{min}$ using HBS-EP as running buffer. After the injections, the responses were measured (dotted line) and used for the construction of the calibration curve (insert). The binding of the ER was regenerated by the injection of $10 \mathrm{mM} \mathrm{NaOH}$ for $0.5 \mathrm{~min}$. The total time of each cycle was $11 \mathrm{~min}$ of which 5 min were used for the transfer and mixing. 
The optimized set-up was then used to test water samples with an expected level of EDCs in the order of low ppt (pg/mL). Since our assay works at the low ppb level (range of the calibration curve was from $0.5-10 \mathrm{ng} / \mathrm{mL}$ (Figure 3)), the water samples were concentrated up to 200 by SPE. In order to prove the robustness of the bioassay, several water samples (millipore water (MQ), drinking water, process water, water from a fish farm and river water samples) were tested with and without E2 spiking. MQ water sample was spiked with 0, 10, 20 and 50 ppt of E2, pre-concentrated by SPE from 50 to $0.25 \mathrm{~mL}$ (200 times), and the obtained responses (and recoveries) were 10, 80 (60\%), 230 (64\%) and $370 \mathrm{RU}$ (37\%), respectively. Although the recoveries varied between 37 and 64\%, the 10 ppt E2 addition was clearly detectable and the limit of detection was estimated at $<5 \mathrm{ppt}$.

The tap water samples $(n=2)$ and the fish farm water samples (Figure S2 were also analysed in the same way without and with the addition of 20 ppt of E2 and all spiked samples were clearly detected with responses from 120 to 270 RUs (compared with responses of 5 to 18 RUs for the blanks) and with recoveries varying from 38 to $75 \%$.

Real water samples $(n=8)$ from fish farms in the UK $(n=3)$, Slovenia $(n=2$ (Bay of Piran)) and river water samples from Slovenia $(n=3)$, with and without the addition of 50 ppt of E2, were tested after SPE with a 200 times concentration. Prior to their analysis, these real samples were hydrolysed with Helix Pomatia overnight at $37^{\circ} \mathrm{C}$ to convert possible conjugated estrogens (glucuronides and sulphates) into the free compounds.

Sensorgrams of one of the water samples from the UK (SP3), with and without the addition of E2, are shown in Figure S7 together with the responses (insert) obtained with all 8 samples and 2 standard $(10 \mathrm{ng} / \mathrm{mL})$ responses for comparison $(10 \mathrm{ng} / \mathrm{mL}=100 \%$ recovery). The non-spiked real water samples showed responses varying from 12 to $15 \mathrm{RU}$ with an average of $14 \pm 2 \mathrm{RU}$ (corresponding with E2 concentrations in the samples of $<5 \mathrm{ppt}$ ) and the spiked samples from 294 to 416 RU with an average of $374 \pm 39 \mathrm{RU}$ (corresponding with an average recovery of $74 \pm 7 \%$ ). As controls, Millipore Q (MiliQ) samples $(n=2)$ with and without the addition of 50 ppt of E2 were tested which resulted in comparable average responses (12 \pm 0 and $386 \pm 54 \mathrm{RU})$ and a comparable recovery (81\%).

Additional water samples $(n=4)$ taken from a Slovenian fish farm, Slovenian rivers $(n=2)$ and the Gulf of Trieste were tested after a 500 times concentration by SPE and these resulted in an average response of $10 \pm 6 \mathrm{RU}$ which corresponds with a concentration of E2 of $<1$ ppt. The MQ controls (blank and spike at $10 \mathrm{ppt}$ ) gave responses of 15 and $469 \mathrm{RU}$ with a recovery of $66 \%$.

No positive water samples were found with the biosensor receptor test except for E2 spiked samples. In order to confirm the results, the same samples were tested by GCMS and no E2 and EE2 and other steroids were detected $(<5 \mathrm{ppt})$ and the average recovery of the 50 ppt spiked samples $(n=8)$ was $76 \pm 7 \%$. The comparison of the data proves that $w \mathrm{t}-\mathrm{ER} \alpha^{\mathrm{LBD}}$ bioassay is reliable and it can be successfully used to determine the amount of E2 in real water samples at low ppt levels.

\subsection{Array of ERa Receptors Mutants}

In this work, the SPR experiments have been performed to test the peptide-specific recognition of the conformation of complexes formed by wt-ER $\alpha^{\mathrm{LBD}}$ and the mutants M421F-ER $\alpha^{\mathrm{LBD}}$ and M421I-ER $\alpha^{\text {LBD }}$ with agonist and antagonist compounds [28]. The mutant Y537S-ER $\alpha^{\text {LBD }}$ has been used as positive control because of its permanent ligand-bound mode or active conformation, even in the absence of ligand. The permanent active conformation is due to the substitution of the Tyrosine into Serine amino-acids [44].

Ligand-free receptor was used as a control resulting in a limited amount of interactions with $\alpha \beta /$ I peptides (Figure S8A-C, black line and Figure 4E). This unexpected binding is probably due to the flexible structure of ER $\alpha^{\mathrm{LBD}}$, which may lead to partially active conformation [45]. Besides, the results also show that in the absence of ligand, $\alpha \beta /$ I peptide is able to recognize the permanent active conformation of Y537S-ER $\alpha^{\mathrm{LBD}}$ mutant (Figure 3D, black line). 
After incubation of $\mathrm{ER} \alpha^{\mathrm{LBD}}$ receptors with $1.5 \mu \mathrm{M}$ of E2, EE2, 4-NP or TAM, respectively, different $E R \alpha^{\mathrm{LBD}}$-ligands complexes were flowed over the peptides coated chip and the sensogram is plotted in Figure S8.

In order to determine and compare the increase/decrease of SPR signal for the different ER $\alpha^{\mathrm{LBD}}$ receptors and ligands, we define the parameter $R$ as a ratio:

$$
R=\frac{\text { Intensity }_{\mathrm{ER} \alpha^{\mathrm{LBD}}-\text { ligand }}-\text { Intensity }_{\text {free }-\mathrm{ER} \alpha^{\mathrm{LBD}}}}{\text { Intensity }_{\text {free }-\mathrm{ER} \alpha^{\mathrm{LBD}}}}
$$

This parameter indicates the increasing (or decreasing) amount of ER $\alpha^{\mathrm{LBD}}$ in the active conformation normalized to free $\mathrm{ER} \alpha^{\mathrm{LBD}}$. In Figure 4 , the parameter $R$ (Active $\mathrm{ER} \alpha^{\mathrm{LBD}} /$ ligand) is plotted for each ER $\alpha^{\mathrm{LBD}}$ mutant (wt-ER $\alpha^{\mathrm{LBD}}$, M421F-ER $\alpha^{\mathrm{LBD}}, \mathrm{M} 421 \mathrm{I}-\mathrm{ER} \alpha^{\mathrm{LBD}}$, Y537S-ER $\alpha^{\mathrm{LBD}}$ ) and for the ligands E2, EE2, 4-NP and TAM.
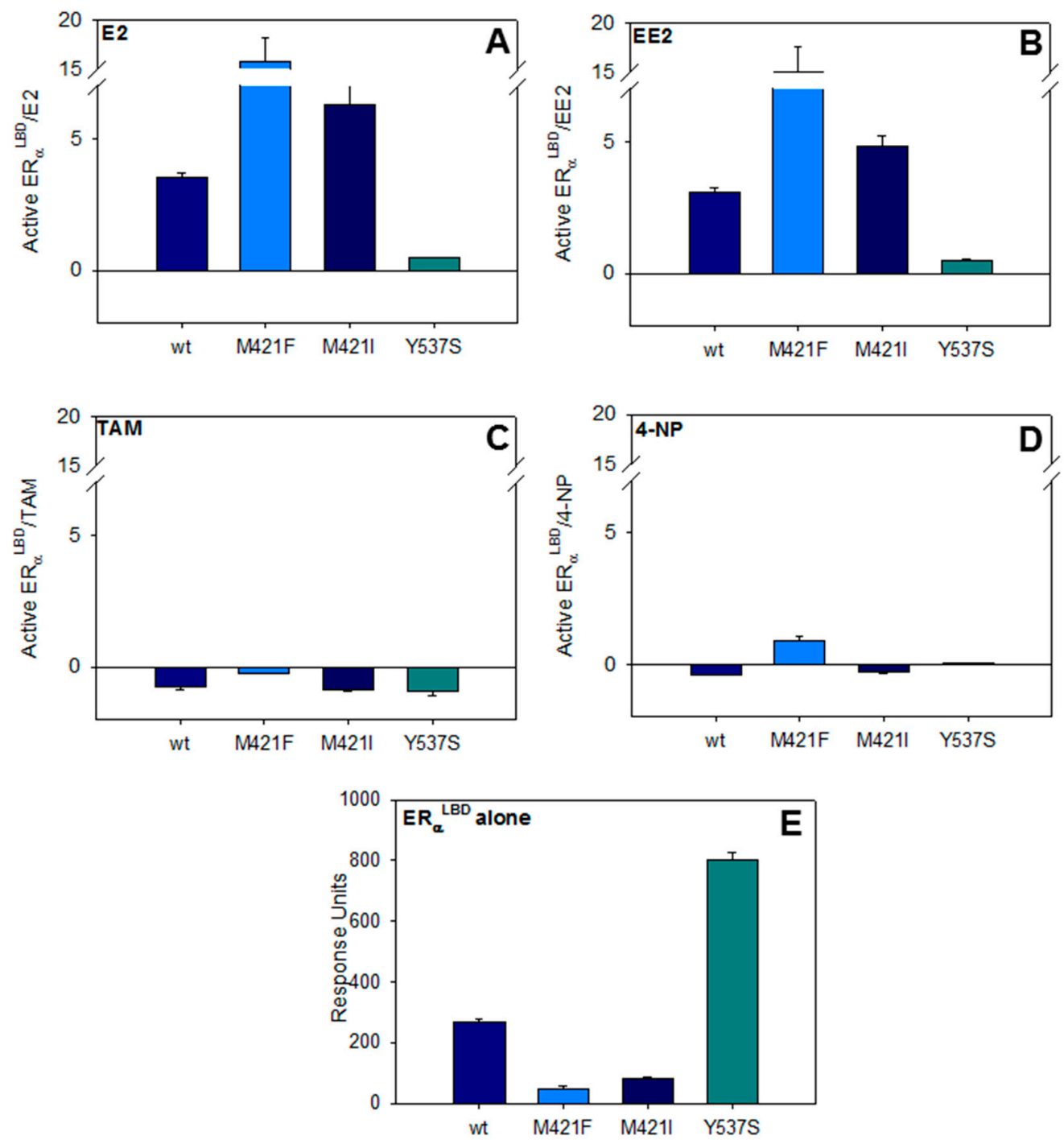

Figure 4. Comparative ratio of $\mathrm{ER} \alpha^{\mathrm{LBD}}$ ligands complexes towards the ligands (A) 17 $\beta$-estradiol (E2); (B) ethinyl-estradiol (EE2); (C) 4-OH tamoxifen (TAM); (D) 4-nonylphenol (4-NP); and (E) ERs free binding response.

In Figure 4 , the $R$ of each ligand (Active ER $\alpha^{\mathrm{LBD}} /$ ligand), incubated with ER $\alpha^{\mathrm{LBD}}$ mutants and flowed over the $\alpha \beta /$ I peptide, are presented. 
E2 and EE2, incubated with ER $\alpha^{\mathrm{LBD}}$ mutants provoke a clear positive ratio $R$ with a modulated response in the following order: Y537S-ER $\alpha^{\mathrm{LBD}}<\mathrm{wt}-\mathrm{ER} \alpha^{\mathrm{LBD}}<\mathrm{M} 421 \mathrm{I}-\mathrm{ER} \alpha^{\mathrm{LBD}}<\mathrm{M} 421 \mathrm{~F}-\mathrm{ER} \alpha^{\mathrm{LBD}}$ (Figure 4, Panels A and B). This trend is probably due to the higher affinity of M421F-ER $\alpha^{\mathrm{LBD}}$ for E2 and EE2 [28] as compared to other receptor which results in a higher percentage of M421F-ER $\alpha^{\mathrm{LBD}}$ in the active conformation, that is, higher recognition by $\alpha \beta / \mathrm{I}$ peptides. As expected, the ratio $R$ resulting from the binding of Y537S-ER $\alpha^{\mathrm{LBD}}$ complex formed with strong agonists to $\alpha \beta / \mathrm{I}$ peptide is only marginally increased because of its natural, active conformation even in the absence of agonist ligands as mentioned above [44].

The evidence of the Y537S-ER $\alpha^{\mathrm{LBD}}$ mutant being in a high percentage in the active conformation is much clearer observing Figure $4 \mathrm{E}$ where it is possible to observe the different amount of the ligand-free mutants being in active conformation (Y537S-ER $\alpha^{\mathrm{LBD}}>$ wt-ER $\alpha^{\mathrm{LBD}}>\mathrm{M} 421 \mathrm{I}-\mathrm{ER} \alpha^{\mathrm{LBD}}$ $>\mathrm{M} 421 \mathrm{~F}-\mathrm{ER} \alpha^{\mathrm{LBD}}$ ).

The SPR responses are noticeably different for TAM (Figure 4, Panel C) where the normalized ratio $(R)$ for all ER $\alpha^{\mathrm{LBD}}$ mutants is found negative since the SPR signal for ER $\alpha^{\mathrm{LBD}}$-TAM complexes is lower than the reference (ligand free ER $\alpha^{\mathrm{LBD}}$ ). This result confirms the interaction between TAM and the mutants binding pocket inducing a conformational change in an antagonist bound conformation, which is not recognized by $\alpha \beta / \mathrm{I}$ peptide.

The weak agonist ligand 4-NP, generates a positive $R$ for M421F-ER $\alpha^{\mathrm{LBD}}$ mutant (Figure $4 \mathrm{D}$, cyan) and negative $R$ for the other mutants (Figure 4D). The lower affinity of 4-NP for ER $\alpha^{\mathrm{LBD}}$ does not allow to establish a clear SPR response trend; however, the statistical relevance of the data is demonstrated by $t$-test. In details, the comparison of the SPR response for ligand free and 4-NP bound $w t-E R \alpha^{\mathrm{LBD}}$, M421F-ER $\alpha^{\text {LBD }}$ and M421I-ER $\alpha^{\text {LBD }}$ are significantly different (p values calculated by $t$-test are 0.0002 , 0.0002 and 0.0004 , respectively) whereas for Y537S-ER $\alpha^{\mathrm{LBD}}$ the $t$-test is not significantly different ( $p$ value 0.4154 ). From these analyses, it is tempting to say that the 'positive /negative' $R$ pattern might indicate the presence of weak agonists in an unknown sample.

These results suggest that the array of mutants can be used advantageously for a fast screening of the presence of agonist/antagonist compounds in an unknown sample. In specific, clear positive and negative $R(R>1$ or $R<1)$ for the four receptors suggest the presence of an agonist or antagonist compounds, respectively. The combination of positive and negative $R$ might indicate the presence of weak agonists. These different ratio pattern can thus give important information on the presence or not of potential estrogenic compounds in unknown samples that have to be nevertheless further identified in cellular environment.

To improve the identification capability of the compound by the present assay, more studies need to be carried out focusing on the determination of the relative ratio $R$ of the studied mutants for more compounds at different concentrations. The large number of variable (concentration, EDCs compounds with associated affinity towards $E R \alpha^{\mathrm{LBD}}$ ) need to be integrated by an algorithm analysis for further pattern recognition analysis.

The present assay is complementary to conventional methods of determination of (anti)estrogenic activity traditionally performed by ER-CALUX, MELN, T47D-KBLuc and the Yeast Estrogen Screen (YES) assays. These tests are all cells-based bioassays requiring stably transfected transcriptional activation of responsive elements (luciferase for the three former assays and galactosidase for the last) [7].

Indeed, the SPR assay developed in this study allows discriminating the presence of an antagonist ligand from a situation where no ligand is present in a sample (see Figure 3). These two events are not distinguishable on cell-based assays, unless a co-injection of an agonist is carried out. Furthermore, the cell-based assay can be affected by different mechanisms, such as cytotoxicity and bioavailability of the compounds, while the SPR response is a direct measurement of binding of a compound. In addition, $\mathrm{ER} \alpha^{\mathrm{LBD}}$ assay is performed in $1 \mathrm{~h}$ rather than $24 \mathrm{~h}$ as required for a cell-based assay. Moreover, being a cell free assay, it does not need specific laboratory equipment and qualified personnel. Finally ER $\alpha^{\mathrm{LBD}}$ assay can detect different compounds at the same time by using different $\mathrm{ER} \alpha^{\mathrm{LBD}}$ mutants and 
multiple channels (Figure S1). The advantage of using a cell-based bioassays is the higher sensitivity (20-40 pg/L for E2) [7] in comparison to ER $\alpha^{\mathrm{LBD}}$ assay ( $20 \mathrm{ng} / \mathrm{L}$ for E2); however, the sensitivity issue can be overcome by pre-concentrating the sample [43].

\section{Conclusions}

In conclusion, a SPR-based assay was designed for measuring the binding of agonist and antagonist compounds to ER $\alpha^{\mathrm{LBD}}$. This assay is based on the immobilization of $\alpha \beta / \mathrm{I}$ biotinylated peptide, which specifically recognizes the conformational change of $E R \alpha^{\mathrm{LBD}}$ upon binding to $\mathrm{E} 2$. This assay system allows easier detection of small molecules by SPR, since it is based on the ability of the $\alpha \beta /$ I peptide to specifically recognize the $E R_{\alpha}{ }^{\mathrm{LBD}}$-E2 complex, thus leading to a great change in SPR response. The limit of detection of the SPR assay is $0.60 \mathrm{ng} / \mathrm{mL}$ for wt-ER $\alpha^{\mathrm{LBD}}$-E2 complex, which can be improved by pre-concentrating the sample. E2 spiked real water sample were successfully tested by wt-ER $\alpha^{\mathrm{LBD}}$-E2 bioassay after SPE concentration and the results are in agreement with the GC MS data. Moreover, an array of engineered estrogen receptors (wt-ER $\alpha^{\mathrm{LBD}}, \mathrm{M} 421 \mathrm{~F}-\mathrm{ER} \alpha^{\mathrm{LBD}}$, M421I-ER $\alpha^{\mathrm{LBD}}$ and Y537S-ER $\alpha^{\mathrm{LBD}}$ ) is screened with E2, EE2, 4-NP and TAM ligands.

The results show that the $\alpha \beta /$ I peptide is able to distinguish between the ER $\alpha^{\mathrm{LBD}_{\mathrm{S}}}$ bound to strong agonists, (E2, EE2), weak agonist (4-NP) and antagonist (TAM) molecules.

The assay which combines of the use of conformation-sensitive peptide and an array of ER $\alpha$ mutants with different affinities toward EDC compounds is a very promising tool for detecting the presence of/and potential estrogenic activity of chemicals through their binding to the ER $\alpha^{\mathrm{LBD}}$. In addition, the regeneration capability of the platform and its adaptability to a portable SPR device make this assay promising for screening of EDCs in field.

Supplementary Materials: The following are available online at www.mdpi.com/2079-6374/8/1/1/s1.

Acknowledgments: RADAR FP7 project funds FP7-KBBE/Programme Cooperation-Research Theme: Food, agriculture and fisheries, and biotechnology, project number 265721). L.V. and M.P. acknowledge financial support by SNF 138518. We thank all the partners from this project for their contributions to the developments of the assays and gathering the sample materials.

Author Contributions: L.V., L.C., T.L., P.C. R.L.S., V.E.V.F. and W.H. conceived and designed the experiments; R.L.S., V.E.V.F., V.A., M.P., W.H. performed the experiments; R.L.S. and W.H., P.C. analyzed the data; L.V., W.H., P.C., T.L., contributed reagents/materials/analysis tools; R.L.S., V.E.V.F., L.V., W.H. and P.C. wrote the paper." Authorship must be limited to those who have contributed substantially to the work reported.

Conflicts of Interest: The authors declare no conflict of interest.

\section{References}

1. Kortenkamp, A.; Martin, O.; Faust, M.; Evans, R.; McKinlay, R.F.; Orton, F.; Rosivatz, E. State of the art assessment of endocrine disrupters. Final Rep. 2011, 23, 1-135.

2. Waring, R.H.; Harris, R.M. Endocrine disrupters: A human risk? Mol. Cell. Endocrinol. 2005, 244, 2-9. [CrossRef] [PubMed]

3. Jeselsohn, R.; Yelensky, R.; Buchwalter, G.; Frampton, G.; Meric-Bernstam, F.; Gonzalez-Angulo, A.M.; Ferrer-Lozano, J.; Perez-Fidalgo, J.A.; Cristofanilli, M.; Gomez, H.; et al. Emergence of constitutively active estrogen receptor-alpha mutations in pretreated advanced estrogen receptor-positive breast cancer. Clin. Cancer Res. 2014, 20, 1757-1767. [CrossRef] [PubMed]

4. Gomes, R.L.; Lester, J.N. Endocrine Disrupters in Drinking Water and Water Reuse; CRC Press: London, UK, 2002; pp. 219-266.

5. $\quad$ Diamanti-Kandarakis, E.; Bourguignon, J.P.; Giudice, L.C.; Hauser, R.; Prins, G.S.; Soto, A.M.; Zoeller, R.T.; Gore, A.C. Endocrine-disrupting chemicals: An Endocrine Society scientific statement. Endocr. Rev. 2009, 30, 293-342. [CrossRef] [PubMed]

6. Locatelli, M.; Sciascia, F.; Cifelli, R.; Malatesta, L.; Bruni, P.; Croce, F. Analytical methods for the endocrine disruptor compounds determination in environmental water samples. J. Chromatogr. A 2016, 1434, 1-18. [CrossRef] [PubMed] 
7. Carvalho, R.N.; Arukwe, A.; Ait-Aissa, S.; Bado-Nilles, A.; Balzamo, S.; Baun, A.; Belkin, S.; Blaha, L.; Brion, F.; Conti, D.; Creusot, N.; et al. Mixtures of chemical pollutants at European legislation safety concentrations: How safe are they? Toxicol. Sci. 2014, 141, 218-233. [CrossRef] [PubMed]

8. Omar, T.F.T.; Ahmad, A.; Aris, A.Z.; Yusoff, F.M. Endocrine disrupting compounds (EDCs) in environmental matrices: Review of analytical strategies for pharmaceuticals, estrogenic hormones, and alkylphenol compounds. TrAC Trends Anal. Chem. 2016, 85, 241-259. [CrossRef]

9. Marchesini, G.R.; Meulenberg, E.; Haasnoot, W.; Irth, H. Biosensor immunoassays for the detection of bisphenol A. Anal. Chim. Acta 2005, 528, 37-45. [CrossRef]

10. Ojeda, I.; Lopez-Montero, J.; Moreno-Guzman, M.; Janegitz, B.C.; Gonzalez-Cortes, A.; Yanez-Sedeno, P.; Pingarron, J.M. Electrochemical immunosensor for rapid and sensitive determination of estradiol. Anal. Chim. Acta 2012, 743, 117-124. [CrossRef] [PubMed]

11. Pires, N.M.; Dong, T. Ultrasensitive opto-microfluidic immunosensor integrating gold nanoparticle-enhanced chemiluminescence and highly stable organic photodetector. J. Biomed. Opt. 2014, 19, 30504. [CrossRef] [PubMed]

12. Zhang, S.; Du, B.; Li, H.; Xin, X.; Ma, H.; Wu, D.; Yan, L.; Wei, Q. Metal ions-based immunosensor for simultaneous determination of estradiol and diethylstilbestrol. Biosens. Bioelectron. 2014, 52, 225-231. [CrossRef] [PubMed]

13. Coille, I.; Reder, S.; Bucher, S.; Gauglitz, G. Comparison of two fluorescence immunoassay methods for the detection of endocrine disrupting chemicals in water. Biomol. Eng. 2002, 18, 273-280. [CrossRef]

14. Beato, M. Gene regulation by steroid hormones. Cell 1989, 56, 335-344. [CrossRef]

15. Katzenellenbogen, B.S.; Katzenellenbogen, J.A. Estrogen receptor transcription and transactivation: Estrogen receptor alpha and estrogen receptor beta: Regulation by selective estrogen receptor modulators and importance in breast cancer. Breast Cancer Res. 2000, 2, 335-344. [CrossRef] [PubMed]

16. Pettersson, K.; Gustafsson, J.A. Role of estrogen receptor beta in estrogen action. Annu. Rev. Physiol. 2001, 63, 165-192. [CrossRef] [PubMed]

17. Strauss, L.; Kallio, J.; Desai, N.; Pakarinen, P.; Miettinen, T.; Gylling, H.; Albrecht, M.; Makela, S.; Mayerhofer, A.; Poutanen, M. Increased exposure to estrogens disturbs maturation, steroidogenesis, and cholesterol homeostasis via estrogen receptor alpha in adult mouse Leydig cells. Endocrinology 2009, 150, 2865-2872. [CrossRef] [PubMed]

18. Colasanti, T.; Maselli, A.; Conti, F.; Sanchez, M.; Alessandri, C.; Barbati, C.; Vacirca, D.; Tinari, A.; Chiarotti, F.; Giovannetti, A.; et al. Autoantibodies to estrogen receptor alpha interfere with T lymphocyte homeostasis and are associated with disease activity in systemic lupus erythematosus. Arthritis Rheum. 2012, 64, 778-787. [CrossRef] [PubMed]

19. Ribas, V.; Drew, B.G.; Le, J.A.; Soleymani, T.; Daraei, P.; Sitz, D.; Mohammad, L.; Henstridge, D.C.; Febbraio, M.A.; Hewitt, S.C.; et al. Myeloid-specific estrogen receptor alpha deficiency impairs metabolic homeostasis and accelerates atherosclerotic lesion development. Proc. Natl. Acad. Sci. USA 2011, 108, 16457-16462. [CrossRef] [PubMed]

20. Chung, A.C.; Cooney, A.J. The varied roles of nuclear receptors during vertebrate embryonic development. Nucl Recept Signal. 2003, 1. [CrossRef] [PubMed]

21. Kumar, R.; Thompson, E.B. The structure of the nuclear hormone receptors. Steroids 1999, 64, 310-319. [CrossRef]

22. Shiau, A.K.; Barstad, D.; Radek, J.T.; Meyers, M.J.; Nettles, K.W.; Katzenellenbogen, B.S.; Katzenellenbogen, J.A.; Agard, D.A.; Greene, G.L. Structural characterization of a subtype-selective ligand reveals a novel mode of estrogen receptor antagonism. Nat. Struct. Biol. 2002, 9, 359-364. [CrossRef] [PubMed]

23. Pike, A.C.; Brzozowski, A.M.; Hubbard, R.E.; Bonn, T.; Thorsell, A.G.; Engstrom, O.; Ljunggren, J.; Gustafsson, J.A.; Carlquist, M. Structure of the ligand-binding domain of oestrogen receptor beta in the presence of a partial agonist and a full antagonist. EMBO J. 1999, 18, 4608-4618. [CrossRef] [PubMed]

24. Paige, L.A.; Christensen, D.J.; Gron, H.; Norris, J.D.; Gottlin, E.B.; Padilla, K.M.; Chang, C.Y.; Ballas, L.M.; Hamilton, P.T.; McDonnell, D.P.; et al. Estrogen receptor (ER) modulators each induce distinct conformational changes in ER alpha and ER beta. Proc. Natl. Acad. Sci. USA 1999, 96, 3999-4004. [CrossRef] [PubMed] 
25. Scott, J.K.; Smith, G.P. Searching for peptide ligands with an epitope library. Science 1990, 249, $386-390$. [CrossRef] [PubMed]

26. Halachmi, S.; Marden, E.; Martin, G.; MacKay, H.; Abbondanza, C.; Brown, M. Estrogen receptor-associated proteins: Possible mediators of hormone-induced transcription. Science 1994, 264, 1455-1458. [CrossRef] [PubMed]

27. Norris, J.D.; Paige, L.A.; Christensen, D.J.; Chang, C.Y.; Huacani, M.R.; Fan, D.; Hamilton, P.T.; Fowlkes, D.M.; McDonnell, D.P. Peptide antagonists of the human estrogen receptor. Science 1999, 285, 744-746. [CrossRef] [PubMed]

28. Ferrero, V.E.; Pedotti, M.; Chiado, A.; Simonelli, L.; Calzolai, L.; Varani, L.; Lettieri, T. Rational modification of estrogen receptor by combination of computational and experimental analysis. PLOS ONE 2014, 9, e102658. [CrossRef] [PubMed]

29. Aqai, P.; Blesa, N.G.; Major, H.; Pedotti, M.; Varani, L.; Ferrero, V.E.; Haasnoot, W.; Nielen, M.W. Receptor-based high-throughput screening and identification of estrogens in dietary supplements using bioaffinity liquid-chromatography ion mobility mass spectrometry. Anal. Bioanal. Chem. 2013, 405, 9427-9436. [CrossRef] [PubMed]

30. Usami, M.; Mitsunaga, K.; Ohno, Y. Estrogen receptor binding assay of chemicals with a surface plasmon resonance biosensor. J. Steroid Biochem. Mol. Biol. 2002, 81, 47-55. [CrossRef]

31. Rich, R.L.; Hoth, L.R.; Geoghegan, K.F.; Brown, T.A.; LeMotte, P.K.; Simons, S.P.; Hensley, P.; Myszka, D.G. Kinetic analysis of estrogen receptor/ligand interactions. Proc. Natl. Acad. Sci. USA 2002, 99, 8562-8567. [CrossRef] [PubMed]

32. Scognamiglio, V.; Antonacci, A.; Patrolecco, L.; Lambreva, M.D.; Litescu, S.C.; Ghuge, S.A.; Rea, G. Analytical tools monitoring endocrine disrupting chemicals. TrAC Trends Anal. Chem. 2016, 80, 555-567. [CrossRef]

33. Nguyen, H.; Park, J.; Kang, S.; Kim, M. Surface Plasmon Resonance: A Versatile Technique for Biosensor Applications. Sensors 2015, 15, 10481-10510. [CrossRef] [PubMed]

34. Zhang, X.-L.; Liu, Y.; Fan, T.; Hu, N.; Yang, Z.; Chen, X.; Wang, Z.-Y.; Yang, J. Design and Performance of a Portable and Multichannel SPR Device. Sensors 2017, 17, 1435. [CrossRef] [PubMed]

35. Sumbayev, V.V.; Jensen, J.K.; Hansen, J.A.; Andreasen, P.A. Novel modes of oestrogen receptor agonism and antagonism by hydroxylated and chlorinated biphenyls, revealed by conformation-specific peptide recognition patterns. Mol. Cell. Endocrinol. 2008, 287, 30-39. [CrossRef] [PubMed]

36. Sumbayev, V.V.; Bonefeld-Jorgensen, E.C.; Wind, T.; Andreasen, P.A. A novel pesticide-induced conformational state of the oestrogen receptor ligand-binding domain, detected by conformation-specific peptide binding. FEBS Lett. 2005, 579, 541-548. [CrossRef] [PubMed]

37. Gao, Y.; Li, X.; Guo, L.H. Assessment of estrogenic activity of perfluoroalkyl acids based on ligand-induced conformation state of human estrogen receptor. Environ. Sci. Technol. 2013, 47, 634-641. [CrossRef] [PubMed]

38. O'Shannessy, D.J.; Brigham-Burke, M.; Pek, K. Immobilization chemistries suitable for use in the BIAcore surface plasmon resonance detector. Anal. Biochem. 1992, 205, 132-136. [CrossRef]

39. Pauwels, S.; Lintermans, A.; Neven, P.; Verhaeghe, J.; Jans, I.; Billen, J.; Vanderschueren, D.; Vermeersch, P. Need for estradiol assays with a lower functional sensitivity in clinical studies examining postmenopausal women treated with aromatase inhibitors. J. Clin. Oncol. 2013, 31, 509. [CrossRef] [PubMed]

40. Ke, Y.; Bertin, J.; Gonthier, R.; Simard, J.-N.; Labrie, F. A sensitive, simple and robust LC-MS/MS method for the simultaneous quantification of seven androgen- and estrogen-related steroids in postmenopausal serum. J. Steroid Biochem. Mol. Biol. 2014, 144, 523-534. [CrossRef] [PubMed]

41. Hinteman, T.; Schneider, C.; Scholer, H.F.; Schneider, R.J. Field study using two immunoassays for the determination of estradiol and ethinylestradiol in the aquatic environment. Water Res. 2006, 40, 2287-2294. [CrossRef] [PubMed]

42. Valdes, M.E.; Marino, D.J.; Wunderlin, D.A.; Somoza, G.M.; Ronco, A.E.; Carriquiriborde, P. Screening concentration of E1, E2 and EE2 in sewage effluents and surface waters of the "Pampas" region and the "Rio de la Plata" estuary (Argentina). Bull. Environ. Contam. Toxicol. 2015, 94, 29-33. [CrossRef] [PubMed]

43. Heub, S.; Tscharner, N.; Monnier, V.; Kehl, F.; Dittrich, P.S.; Follonier, S.; Barbe, L. Automated and portable solid phase extraction platform for immuno-detection of 17 beta-estradiol in water. J. Chromatogr. A 2015, 1381, 22-28. [CrossRef] [PubMed] 
44. Weis, K.E.; Ekena, K.; Thomas, J.A.; Lazennec, G.; Katzenellenbogen, B.S. Constitutively active human estrogen receptors containing amino acid substitutions for tyrosine 537 in the receptor protein. Mol. Endocrinol. 1996, 10, 1388-1398. [PubMed]

45. Ozers, M.S.; Ervin, K.M.; Steffen, C.L.; Fronczak, J.A.; Lebakken, C.S.; Carnahan, K.A.; Lowery, R.G.; Burke, T.J. Analysis of ligand-dependent recruitment of coactivator peptides to estrogen receptor using fluorescence polarization. Mol. Endocrinol. 2005, 19, 25-34. [CrossRef] [PubMed] 